\title{
Diversity and inventorization of angiospermic flora in Dibrugarh district, Assam, Northeast India
}

\author{
Pranati Gogoi \& Namita Nath ${ }^{*}$ \\ Department of Botany, Gauhati University, Guwahati 781 014, Assam, India \\ *Email: nathnamita1@gauhati.ac.in
}

\section{ARTICLE HISTORY}

Received: 03 February 2021

Accepted: 13 May 2021

Available online: 01 July 2021

\section{KEYWORDS}

Angiosperms

Flora

Native

Invasive

Traditional

\section{ABSTRACT}

The floristic composition of the Dibrugarh District of Assam has remained unexplored and the present study on Angiosperms addresses this fact. A total of 462 species of flowering plants belonging to 334 genera under 106 families recorded as per the APG IV system of classification and 116 families were recorded according to Bentham and Hooker system. $39 \%$ of native species were included in superorder Superrosids, $29 \%$ from superorder Superasterids, $18 \%$ from superorder Monocots and $7 \%$ from superorder Magnoliids. The orders with the highest number of native species were Lamiales (35), Malpighiales (29), Rosales (26), Gentianales (23), Sapindales (18), Fagales (19), Alismatales (17), Poales (14), Zingiberales (13) and Laurales (11) which accounted for $60.8 \%$ of the species. A total of 129 nonnative or invasive species were represented in 12 superorders. Habit analysis showed that herbs were represented by the highest proportion followed by trees, shrubs and climbers. Twenty species are listed under various IUCN threat categories and one species under Convention on International Trade in Endangered Species of Wild Fauna and Flora (CITES). Traditional uses of some reported species were also documented. The present study was conducted to understand the diversity of local flora, which can be helpful in the conservation of natural vegetation and sustainable utilisation of resources in this region.

\section{Introduction}

Biodiversity functions in all kinds of the ecosystem, which harbours the formation of different habitats (1). These habitats are home to different plant resources, which provide services through natural vegetation and play an important role in regulating the function and monitoring the stability of the ecosystem. Due to the increasing rate of land degradation and overexploitation of natural resources, there is an immense loss of habitats and vegetation. Forests are degraded due to industrialisation, mining and other commercial purposes. The destruction of tropical forests and habitats causes global biodiversity degradation (2). Floristic diversity study helps us to evaluate the floristic wealth and its prospects of an area. Floristic inventories help us perceive biological aspects such as endemism, evolution, speciation and isolation (3). It helps to assess the country's plant wealth, distribution and status (4). There are 15000 species of flowering plants in India belonging to 2250 genera and 315 families, contributing $6 \%$ of World's flowering plants (5). The present number of flowering plants in India is found to be 18666 species under 2991 genera and 251 families (6). If we compare the data regarding endemism, it is clear that in the year 2011, the number of genera endemic to India was 49 (7), but in the year 2019, the number increased to 58 genera and 4303 taxa (8). This may be due to extensive exploration. There is a long history of floristic diversity studies being carried out in different parts of Assam for the past two centuries. Understanding the flora of a region is so complex that its conservation cannot be measured without botanical investigation and scientific analysis. Many workers had earlier contributed to the flora of Assam (9-17), including a detailed account of the Flora of Assam (18). Contribution on a comprehensive checklist of both the angiosperms and gymnosperms of the State was carried out (19). Many authors who carried out floristic works in different districts and protected areas of Assam (20-33). There are many areas of the State where a detailed floristic study is yet to be carried out. No account of the flora of the Dibrugarh district has been carried out. Hence, the present work can be considered as the right step to understanding the flora, which will help assess the regional biodiversity. Despite the richness of flora and high endemism, no attempt has been made for the systemic investigation of angiosperm flora of this region. The 
main objectives of the present study are: (i) to make an inventory of the angiosperms of Dibrugarh District (ii) classification of the angiosperms according to APG IV (Angiosperm Phylogeny Group IV) and Bentham and Hooker system (iii) to document the various traditional uses of plant species by local people. Quantitative inventories help provide valuable information on the structure, diversity of a place, biodiversity conservation and sustainable use of rich diversified plant resources $(34,35)$.

\section{Materials and Methods}

\section{Study area}

Assam is one of the seven states of Northeast India, Arunachal Pradesh and Bhutan surround in the North, Manipur, Nagaland and Arunachal Pradesh in the East, Mizoram and Meghalaya in the South and Tripura, West Bengal and Bangladesh in the West. The geographical area of Assam is $78438 \mathrm{sq} \mathrm{km}$ accounting for about $2.39 \%$ of the country (36).

Dibrugarh is the easternmost part of the State covering an area of about $3381 \mathrm{sq} \mathrm{km}$ extending from $27^{\circ} 5^{\prime}-38^{\prime \prime}-\mathrm{N}$ to $27^{\circ} 42^{\prime}-30^{\prime \prime}-\mathrm{N}$ latitude and $94^{\circ} 33^{\prime}-46^{\prime \prime}-\mathrm{E}$ to $95^{\circ} 29^{\prime}-8^{\prime \prime}-\mathrm{E}$ longitude (37). In the North it is surrounded by the Dhemaji district and Brahmaputra River. In the east it is surrounded by Tinsukia district, Arunachal Pradesh to the South-east and Sivsagar district to the South-west (Fig. 1). During heavy rain and flood, the mineral and silts deposited in the Brahmaputra river come down to the lowland area making the soil fertile for cultivation. Other environmental factors such as temperature, atmospheric pressure, rainfall, humidity enhance the luxuriant vegetation and diversity of the region (3840).

\section{Data Collection}

Plant specimens were collected from different habitats of the district of Dibrugarh through several field trips approximately, 150 days covering all seasons during 2018-2020. The habitats from where the collection was carried out included forests, wetlands, river banks, roadsides as well as private gardens. With the help of local inhabitants, the plants were collected from the respective sites and the vernacular names of the plants were also recorded in a structured questionnaire, comprising of the botanical name, family, habit of the plant, local names and application. The plants were collected mainly during the flowering stage for proper identification. Data collection was carried out based on standard procedures (41-43).

During the field survey, collection of specimen for floristic study, plant specimen were collected, photograph were taken, field data were also recorded in the field notebook, emphasising those characteristics which may not be easily observed in dried specimens. Herbarium specimens of the collected plants were made by following the standard herbarium technique (44). For proper taxonomic identification, the plant specimens were examined by consulting Flora of Assam (11); A checklist of angiosperms and gymnosperms (19). Other literature like eflora of China, online databases like The Plant List (www.theplantlist.org), The International Plant Name Index (www.ipni.org). The plants were enumerated and the arrangement was made according to Angiosperm Phylogeny Group IV Classification (45). The voucher specimens of the

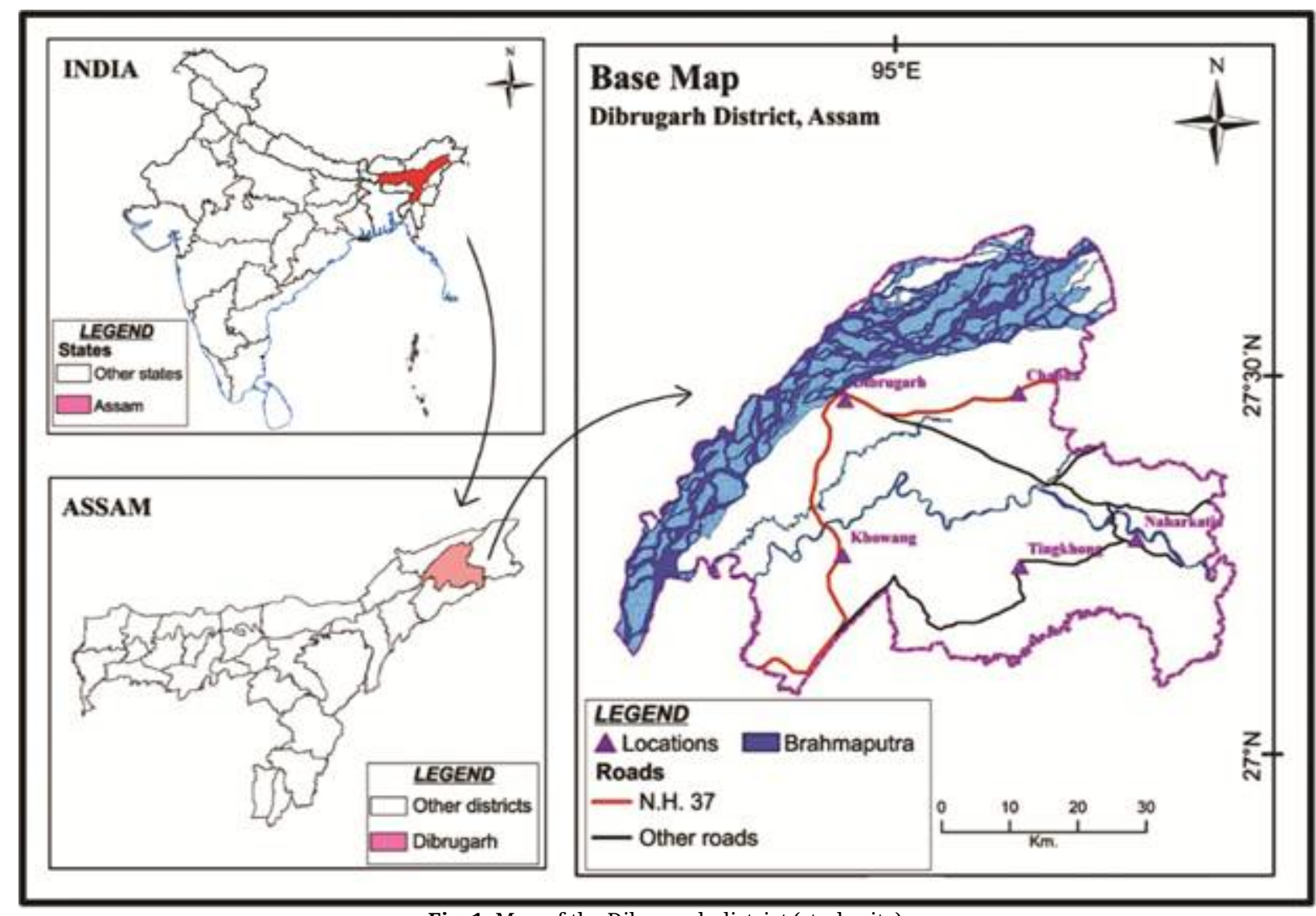

Fig. 1. Map of the Dibrugarh district (study site). 
collected plants were deposited in the Gauhati University Botanical Herbarium (GUBH) of the Department of Botany, Gauhati University, Assam.

\section{Results}

The present study documented 462 species (319 native species; 69\% and 129 non-native species; 28\%) distributed under 334 genera, representing 106 families as per APG IV classification and 116 families as per Bentham and Hooker system (Table 1). These taxa were distributed under 12 superorders (Fig. 2) and 35 orders. Out of the 36 orders, the ten orders that represented the highest number of native species in the district were Lamiales [35], Malpighiales [29], Rosales [26], Gentianales [23], Sapindales [18], Fagales [19], Alismatales [17], Poales [14], Zingiberales [13] and Laurales [11] (Fig. 3) which accounted for $60.8 \%$ of the species. Among the 106 families, the top families with the highest number of native species were depicted in Fig. 4. Native species

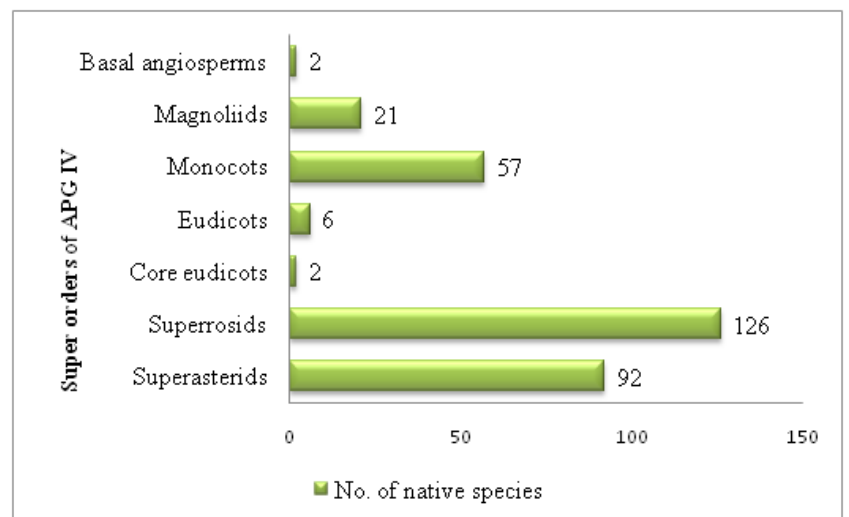

Fig. 2. Number of native species under superorders of APG IV.

are indigenous to a particular region as opposed to an introduced or invasive species.

According to APG IV classification the highest number of native species were found in the family Fabaceae [16], Lamiaceae [15], Araceae and Moraceae [13] each, Rubiaceae [12], Acanthaceae, Lauraceae, Poaceae [11] each, Achariaceae and Apocynaceae [10] each. The genus Ficus represented the highest number of species (9) followed by Garcinia, Clerodendrum and Cassia with six species each, Ipomoea and Polygonum with five species each, Solanum, Cinnamomum, Litsea, Cyperus, Zingiber and Phyllanthus with four species each.

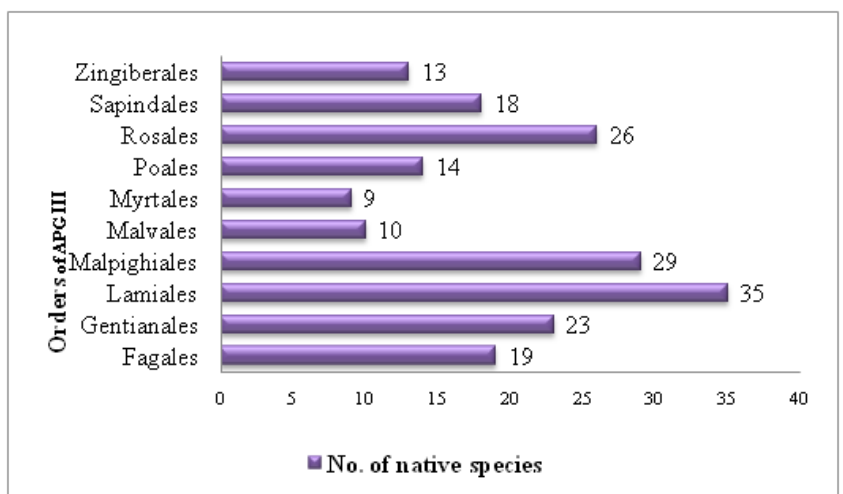

Fig. 3. Number of native species under orders of APG IV.
According to APG IV classification, the ten dominant families based on species richness are Asteraceae (28 genera, 32 species), Fabaceae (16 genera, 23 species), Poaceae (14 genera, 19 species), Lamiaceae (12 genera, 17 species), Malvaceae (10 genera, 16

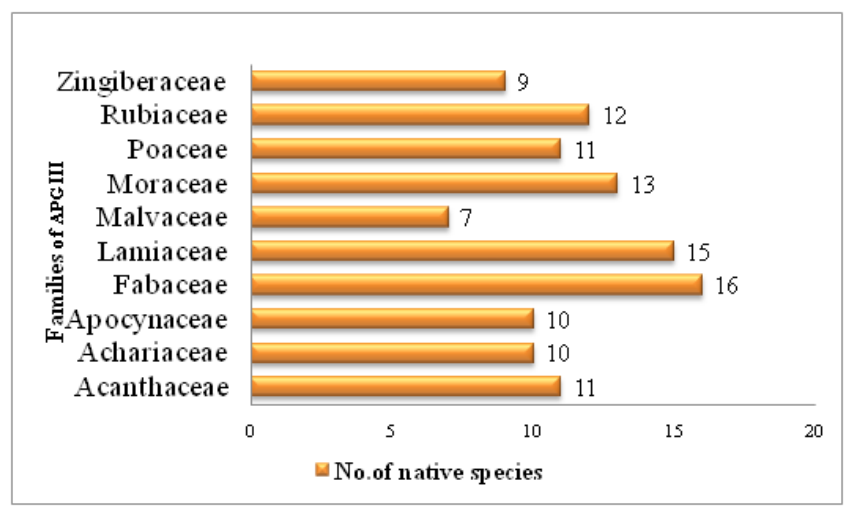

Fig. 4. Number of species under top ten families of APG IV.

species), Araceae (12 genera, 15 species), Apocynaceae (13 genera, 14 species), Rubiaceae (11 genera, 14 species), Moraceae (5 genera, 13 species) and Lauraceae (6 genera, 12 species) (Fig. 5). Habit analysis showed that herbs were represented by the highest proportion with 211 species [46\%], including aquatic and epiphytic, trees by 112 species [24\%], shrubs by 88 species [19\%] and climbers by 53 species [11\%] (Fig. 6). Out of the 462 species, 236 species were found to have economic importance. These are used as medicine, food, cosmetics, dye, fodder, furniture, rituals, biofencing and artefacts by the people in the district (Fig. 7). Out of the 236 economically important plants, 88 species were claimed to have medicinal properties, which the people used to cure different ailments such as gastrointestinal disorders, external injuries, urinogenital, hormonal, lymphatic, infections etc. Medicinal plants accounted for the highest proportion of species representing $37.28 \%$, followed by wild edible plants $(57,24.15 \%)$. The plants used as vegetables and fruits are eaten cooked or raw based on dietary habits. Many plants are also used as fodder (25, 11\%). Timber yielding plants are used as wood $(17,7.20 \%)$ to construct houses, bridges and furniture. Plants like Jatropha curcas L., Ricinus communis L. are also found to grow luxuriantly which has tremendous potential to be used as biofuel. Plants used in ritual $(15,6.35 \%)$ plays a social role in festivals and ceremonies. Different species of Bamboo are used as biofencing (14, 5.9\%).

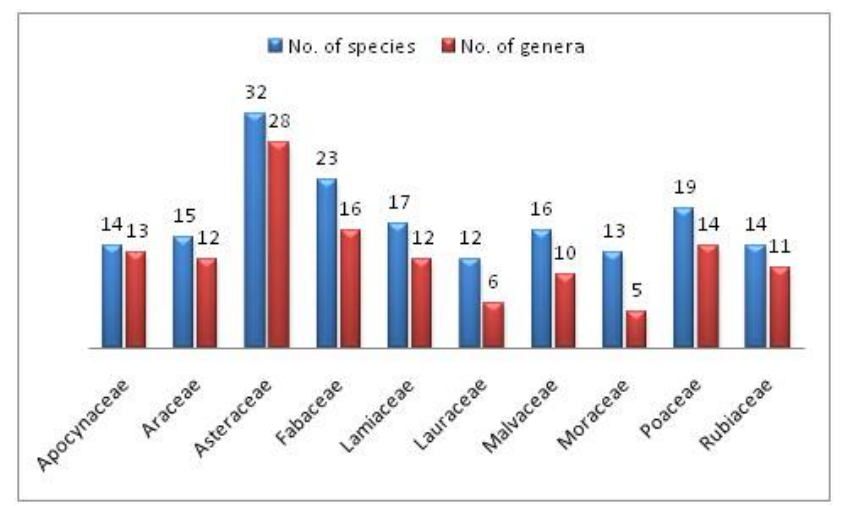

Fig. 5. Species diversity in ten dominant families of Dibrugarh district. 
The bark, leaf and seeds of some plants are a good source of dye (13, 5.5\%) used for colouring clothes, fabrics and utensils like earthenwares. Plants with antibacterial property and yielding essential oil are used as cosmetics $(7,2.9 \%)$ to treat hair and skin (Fig. 7). In the present study, out of 462 recorded species nine species viz. Acorus calamus L., Clerodendrum colebrookianum Walp. Rotheca

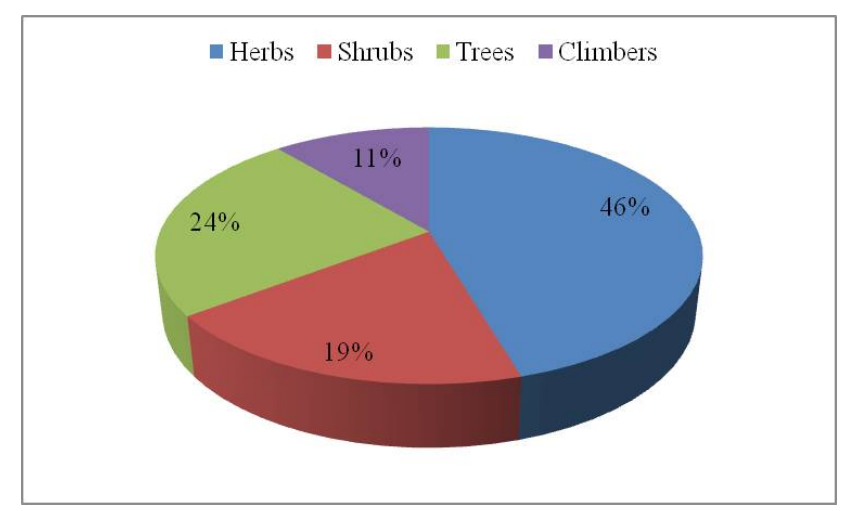

Fig. 6. Analysis of habit forms in the Flora of Dibrugarh district.

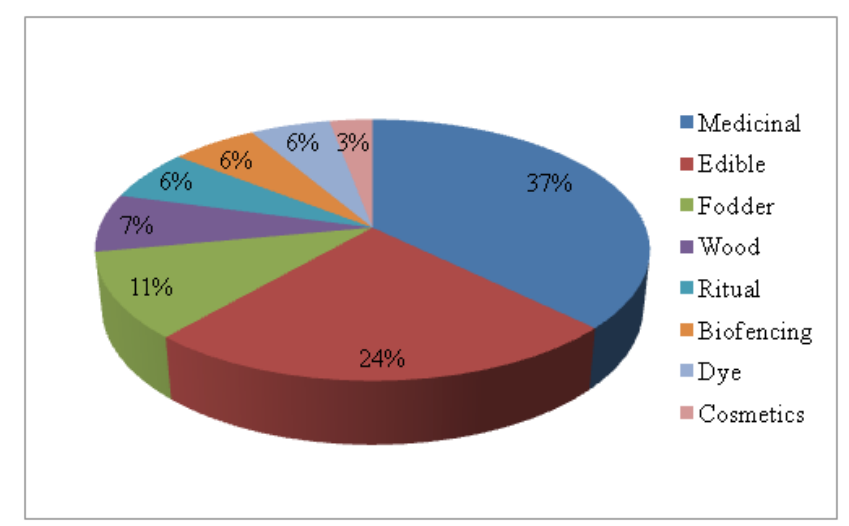

Fig. 7. Traditional plants used by local people for different purpose.

serrata (L.) Steane and Mabb., Gynocardia odorata R.Br., Mesua ferrea L., Oroxylum indicum (L.) Kurz., Sapindus mukorossi Gaertn., Ipomoea quamoclit L., Cissampelos pareira L. has listed under the Vulnerable (VU) category of the IUCN red list. Three species viz. Alstonia scholaris (L.) R.Br., Artocarpus lakoocha Buch.-Ham., Terminalia chebula Retz. are listed under Near Threatened (NT) Category (48). Three species viz. Aquilaria malaccensis Lam., Curcuma caesia Roxb. and Vatica lanceifolia (Roxb.) Blume is listed under the Critically Endangered (CR) Category. Three species viz. Hedychium coronarium J.Koenig, Garcinia pedunculata Roxb. ex Buch-Ham, Rauwolfia serpentina (L.) Benth. ex Kurz is listed under the Endangered (EN) category. Rhyncostylis retusa (L.) Blume is the state flower of Assam and listed under Endangered (EN) Category appendix II (with strictly controlled international trade) of CITES (46, 47). Butea monosperma (Lam.) Taub. is listed under Data Deficient (DD) category and Cinnamomum tamala (Buch.-Ham.) T.Nees and C.H.Eberm is listed under the Least Concern (LC) category of IUCN red list (48). Phoebe bootanica (Meisn.) M. Gangop. and Shorea assamica Dyer is endemic to Assam and has high economic importance for medicinal properties and timber.

\section{Discussion}

The total number of angiosperms reported from the Dibrugarh District presents 462 species belonging to 334 genera and 106 families shows a similar agreement with other floristic studies previously carried out in different regions of India. An inventory of the native flowering plants in the East Siang district of Arunachal Pradesh presented 508 taxa belonging to 348 genera and 102 families (49). Higher plant diversity in East Kameng district of Arunachal Prdesh reported 215 species of higher plants belonging to 165 genera and 70 families (50). Floristic diversity assessment and vegetation analysis of Upper Siang district of Northeast India reported 1003 taxa belonging to 110 families and 529 genera (51). A study of Angiospermic diversity in the Bhadrak region of Odissa showed 383 species including 262 native and 121 non-native species belonging to 282 genera under 93 families (52). No such report has been made from the Dibrugarh district of Assam though several works have been carried out in other parts of the State. From the study, the dominant families were Asteraceae (32 species), Fabaceae (23 species), Poaceae (19 species), Lamiaceae (17 species), Malvaceae (16 species), Araceae (15 species), Apocynaceae (14 species), Rubiaceae (14 species), Moraceae (13 species) and Lauraceae (12 species). Many reports from previous studies showed Asteraceae to be the dominant family (53-59). Among the four different growth habits viz. herbs, trees, shrubs and climbers, the herbaceous community represented the highest number of species (57-59). Some of the economic uses of the collected plant species have been reported where $37 \%$ out of the 235 economically important species were found to possess medicinal properties. Plants that were recommended to cure stomach ailments were Hydrocotyle sibthorpioides Lam., Centella asiatica (L.) Urb., Leucas plukenetti (Roth) Spreng., Paederia scandens (Lour.) Merr., Houttuynia cordata Thunb., Spondias pinnata (L.f.) Kurz. The utility of these plants in gastrointestinal disorders was also cited in previous works by various workers in different parts of Assam $(38,40,60,61)$ and India $(62,63)$. Plants that were most cited for curing diabetes in the present investigation were Catharanthus roseus L., Tinospora cordifolia (Willd.) Hook.f. \& Thomson., Dillenia indica L., Garcinia morella (Gaertn.) Desr. Some works showed these plants to possess anti-diabetic properties (62, 64-66), indicating their effectiveness. Some plants like Aloe vera (L.) Burm.f., Drymaria diandra Bl., Impatiens balsamina L., Curcuma caesia Roxb. is used by people externally to prevent various skin problems, burns, cuts, irritation, pigmentation etc. People also cultivate these herbs for use in an emergency. The application of these plants for skin troubles was also cited by different workers from India $(63,67)$. Some herbs used to cure reproductive problems in the Dibrugarh District are Phyllanthus fraternus L., Bryophyllum pinnatum Roxb., Drymaria diandra $\mathrm{Bl}$. which are highly recommended by traditional healers to patients. These herbs are also found to have similar uses in other parts of Assam (68). The most cited species used in the treatment of Pneumonia by the local people are Piper nigrum L., Zanthoxylum nitidum (Roxb.) DC., Tabernae-montana 
divaricata (L.) R.Br. ex Roem. and Schult., Scoparia dulcis L. $(69,70)$.

Wild edible plants are consumed as food and used in the preparation of traditional recipes. Some of these plants are cultivated in the home gardens and some are collected from the wild. These are also found to be sold in the local markets by village people, thus making them accessible to other people. It was found that, $24 \%$ out of 235 economically important plant species are edible and consumed as raw or cooked by the indigenous people of Dibrugarh District. Some of the commonly found wild edible plants are Dillenia indica L., Flacourtia jangomas Raeusch, Enhydra fluctuans Lour., Alocasia forniculata (Roxb.) Schott, Amorphophallus paeoniifolius (Dennst.) Nicolson, Lasia spinosa (L.) Thw., Homalomena mexicana (Spreng.) Schott, Dioscorea esculenta (Lour.) Burkill, D. pentaphylla L., Livistona jenkensiana Griff., Eichhornia crassipes Solms, Amaranthus viridis L., Chenopodium album L., Myrica esculenta Buch.-Ham. ex D.Don, Artocarpus chama Buch.-Ham. ex Wall., Zanthoxylum oxyphyllum Edgew. These findings showed higher concordant with the other findings reported from Assam and India (71-75).

The local people collect fuelwood from the nearby forests. Both main and sub-branches of trees are chopped as a source of fuel. Apart from fuelwood, some trees are found to be used for the construction of houses, furniture, equipment for farming, fishing, boats etc. In the study, $7 \%$ of plant species were recommended by people as a source of wood. The most commonly used wood tree species are Magnolia griffithii Hook.f. and Thomson. Carallia brachiata (Lour.) Merr., Salix tetrasperma Roxb., Albizia lebbeck (L.) Benth, Lagerstroemia speciosa (L.) Pers., Chukrasia tabularis A. Juss., Dysoxylum binectariferum (Roxb.) Hoof. and f. ex Bedd, Toona ciliata M. Roem., Alstonia scholaris (L.) R.Br., Gmelina arborea Roxb. (49, 76-78). Dipterocarpus retusus Blume is the state tree of Assam that naturally grows in forests in Upper Assam. It is best known for use in plywood industries. Bischofia javanica Blume, Shorea assamica Dyer, Dalbergia sissoo Roxb., Tectona grandis L.f. are used by the local people for construction purposes and artefacts. These trees yield a quality wood product that is favourable for the manufacture of various household items.

Rituals are usually performed during festivals and ceremonies, which are incomplete without using plants (79). Different rituals associated with our life right from birth till death are performed traditionally by offering befitting plant mainly flowers to the deities (80). About $6 \%$ of plant species were found to be used in rituals and festivals. The various plant species that are used to perform rituals and cultural performances in the Dibrugarh District are Ipomoea quamoclit L., Datura metel L., Coix lacryma-jobi L., Cynodon dactylon (L.) Pers., Schumannianthus dichotomus (Roxb.) Gagnep., Alpinia nigra (Gaertn.) Bertt, Elaeocarpus sphaericus (Gaertn.) K. Schum., Acacia farnesiana (L.) Willd., Flemingia strobilifera (L.) R.Br., Ficus benghalensis L., Ficus religiosa L., Rubus moluccanus L., Couroupita guianensis Aubl. and Justicia gendarussa Burm.f. (80).
The use of plants in bio-fencing has been an old practice among the people of the State for protecting the land and sustainable use of natural resources (81) from grazing of animals and encroachment (82). Because of grazing, crop cultivation is hampered to a great extent. Biofencing is therefore essential for the protection of land from massive destruction. It was found that $6 \%$ of plant species were used by the local inhabitants for bio-fencing purposes. These include Duranta repens L., Lantana camara L., Chromolaena odorata (L.) R.King and H. Rob, Monoon longifolium (Sonn.) B.Xue and R.M.K.Saunders, Calamus tenuis Roxb., Bambusa balcooa Roxb., Bambusa tulda Roxb., Bambusa vulgaris Schrader ex J. C. Wendland, Dendrocalamus hamiltonii Nees and Arn. ex Munro, Canna indica L., Erythrina stricta Roxb., Mimosa diplotricha Sauvalle, Ficus rumphii Bl., Dendrocnide sinuata (Blume) Chew and Toona ciliata M. Roem. (81-83).

Dye plants have been used in colouring handlooms, handicrafts by the local people of Dibrugarh District. In India, there are around 450 dye yielding plants used for various purposes $(84,85)$. The natural dyes obtained from these plants are used to colour different clothes by the weaver $(86,87)$. The utilisation of natural dyes over synthetic dyes and its application in textile industries is gaining more interest, providing employment and a source of income to the weaker section in the rural areas (88). The plant species used for natural dye extraction by the local people in the district are Aegle marmelos (L.) Corr., Mallotus phillipensis Muell. -Arg, Trichosanthes tricuspidata Lour., Bauhinia purpurea L., Abrus precatorius L., Acacia farnesiana (L.) Willd., Adenanthera pavonina L., Butea monosperma (Lamk) Taub., Cassia fistula L., Cassia tora L., Punica granatum L., Bixa orellana L. and Chukrasia tabularis A. Juss. (89-96).

Information on seven plants used to treat different skin problems like burns, rashes, prickly heat, pimples and cosmetics were collected from the people of Dibrugarh. The herbal formulas were prepared from different parts of the plant along with water, milk or honey and were administered either orally or externally. The highly recommended plants are Sapindus mukorossi Gaertn., Bacopa monnieri (L.) Wettst., Eclipta alba (L.) L., Centella asiatica (L.) Urb., Magnolia hodgsonii (Hook.f. and Thomson) H.Keng, Aloe vera (L.) Burm.f. and Rosa rugosa Thunb (97, 99). A study showed that $6.3 \%$ of the patients undergo treatment for skin ailment in the medical centres (98). The humid tropical climate enhances the formation of many bacterial and fungal infections on the skin causing irritation and pain. The rural people are mostly associated with agriculture and farming due to which they have to stay outside throughout the day being exposed to dermatological infections (99).

\section{Conclusion}

The present study on angiosperm diversity of the Dibrugarh district is an initiative for monitoring the species composition and checking the changes in diversity caused by several ongoing disturbances. In the 
present work, Angiosperms of the Dibrugarh district are classified according to APG and Bentham and Hooker system. Asteraceae was found to be the largest family in dicots. On the other hand, among monocotyledons, Poaceae was found to be the largest family. $\mathrm{B}$ and $\mathrm{H}$ system is not showing any remarkable difference with the families of APG system. APG IV is followed here because it is one of the most relevant molecular-based systems of classification which is having tremendous attraction all over the world. Along with this system, we adapt Bentham and Hooker system also because till today this system is in use all over India. This work may be helpful for the researchers to carry out floristic study in different regions. The present work focuses on inventorization of angiosperms inorder to establish a comprehensive checklist of the floristic wealth of the district along with traditional knowledge based information which will definitely be helpful in providing sustainable utilization of resources, conservation strategies and management of plant wealth.

\section{Acknowledgements}

The authors express their sincere gratitude to the forest officials and local practitioners of Dibrugarh District for sharing valuable information, for their help and cooperation during the field survey. We are also thankful to the anonymous reviewers for their comments.

\section{Authors' contributions}

Both PG and NN developed the concept of the work. PG carried out the floristic study, collected the data, analysed the data. Both PG and NN identified the species, designed and wrote the manuscript. NN supervised the whole work from the field survey up to the preparation of the report.

\section{Conflict of interests}

The authors declare that they have no competing interests.

\section{Supplementary file}

Table 1. Angiosperm Phylogeny Group (APG IV) Classification of angiosperm taxa from Dibrugarh district.

\section{References}

1. Basha K, Parveen DN. Floristic diversity of Gani reserve forest of Kurnool district, Andhra Pradesh, India with emphasis on medicinal plants. Advances in Biological Research. 2013;7(4):129-35. https://doi.org/10.5829/idosi.abr.2013.7.4.1108

2. Singh SP. Chronic disturbance, a principal cause of environmental degradation in developing countries. Environmental Conservation. 1998;25(1):1-2.

3. Elourard C, Pascal JP, Pelissier R. Monitoring the structure and dynamics of dense moist evergreen forest in the Western Ghats (Kodagu district, Karnaraka, India). Tropical Ecology. 1997;38(2):193-214
4. Ellis JL. Flora of Nallamalais, 1, Fl Ind Ser. 3. Botanical Survey of India, Calcutta, 1987.

5. Nayar MP. Changing patterns of Indian flora. Bulletin of Botanical Survey India. 1977;19:145-54.

6. Mao AA, Dash SS. Plant Discoveries. BSI, Kolkata. 2019;1-163.

7. Irwin SJ, Narasimhan D. Endemic genera of angiosperm in India: a review. Rheedea. 2011;21(1):87-105.

8. Singh P, Karthigeyan K, Lakshminarasimhan P, Dash SS. Endemic Vascular Plants of India. BSI, Kolkata. 2015;339.

9. Carter HG. Useful plants of the district of Lakhimpur, Assam. Rec Bot Surv India. 1921; 69:353-420.

10. Hooker JD. The Flora of British India. Reeve and Co., London. 1872-1892.

11. Kanjilal UN, Kanjilal PC, Dey RN, Das A, Purkayastha C. Flora of Assam, 1 - 4 volumes. Govt. of Assam. Shillong. 1934-1940.

12. Bor NL. Flora of Assam. Calcutta. 1940.

13. Rao AS, Verma DM. Contribution to the botany of North Lakhimpur subdivision, Assam, Bulletin of Botanical Survey of India. 1969;11(3-4):403-13.

14. Kar SK, Panigrahi G. The Rubiaceae in Assam and NEFA Bulletin of Botanical Survey of India. 1963;11(3-4):227-37.

15. Rao AS. Vegetation and Phytogeography of Assam and Myanmar. In: Ecology and Biogeography in India (ed) MS Mani. Junk Publishers. Hague. 1974;204-46.

16. Islam M. Flora of Majuli - the greatest river island in the world. Bishen Singh and Mahendra Pal Singh. Dehradun. 1990.

17. Sarmah JN. A detailed study of the flora of Sibsagar district, Assam. Ph.D. Thesis. Gauhati University, Guwahati. 1989.

18. Chowdhury S. Assam's Flora - present status of vascular plants. Assam Science Technology and Environment Council, Guwahati. 2005.

19. Barooah C, Ahmed I. Plant diversity of Assam - a checklist of Angiosperms and Gymnosperms. Assam Science Technology and Environment Council, Guwahati. 2014.

20. Gogoi P. A detailed study of Golaghat sub-division and its neighbouring areas. Ph. D. Thesis. Gauhati University, Guwahati. 1978.

21. Barua BN. Studies on the systematic of orchids in the Brahmaputra Valley. Ph.D. Thesis. Gauhati University, Guwahati. 1978.

22. Hajra PK. Flora of Kaziranga National Park and Manas Wildlife sanctuary of Assam. Ph.D. Thesis. Gauhati University, Guwahati. 1978.

23. Sarmah JN. A detailed study of the flora of Sibsagar district, Assam. Ph.D. Thesis. Gauhati University, Guwahati. 1989.

24. Barua IC. Systematic studies of the Angiosperms of Kamrup district, Assam. Ph.D. Thesis. Gauhati University, Guwahati. 1992.

25. Sarkar S. Studies on the herbaceous plants of Karbi Anglong district of Assam with reference to their taxonomy and economic utilisation. Ph.D. Thesis. Gauhati University, Guwahati. 1993.

26. Singh R. Systematic studies on the dicotyledonous plants of Lakhimpur district (undivided), Assam. Ph.D. Thesis. Gauhati University, Guwahati. 1993.

27. Nath SM, Choudhury SC. Study of the vegetation and flora of Rajiv Gandhi wildlife sanctuary, Assam. Indian Forester. 1994;940-44.

28. Bora PJ. Flora and Biodiversity of Pabitora wildlife sanctuary in north east India. Ph. D. Thesis. North Eastern Hill University, Shillong. 1999.

29. Bora PJ, Kumar Y. Vegetation of Pabitora wildlife sanctuary in Assam, India. Phytotaxonomy. 2001;98-106.

30. Barooah C, Borthakur SK. Diversity and distribution of bamboos in Assam. Bishen Singh and Mahendra Pal Singh. Dehradun, India. 2003. 
31. Bujarbarua P, Sarma SK. An assessment of the floristic diversity of Gibbon wildlife sanctuary, Assam (India). Phytotaxonomy. 2004;124 -30.

32. Begum SS, Nath M, Roy H, Borthakur SK. Flora of Nameri National Park, Assam: I, Rare, Endangered and Threatened Plants. Pleione. 2010;172-79.

33. Nath SK. Floristic diversity of Nagaon district of Assam, India. International Journal of Science Technology and Management. 2015;549-53.

34. Whitmore TC. An Introduction in Tropical Forests, 2nd edn. Clarendon Press. Oxford and University of Illinois Press, Urbana, USA. 1998;117.

35. Pitman NCA, Terborgh JW, Silman MR, Nunez P, Neill DA, Ceron CE, Palacios WA, Aulestia M. A comparison of tree species diversity in two upper Amazonian forests, Ecology. 2002;83(11):3210-24

36. Census of India 2011. https://www.census2011.co.in/states.php

37. Census of India. 2011.

https://census2011.co.in/census/district/149-dibrugarh.html

38. Kalita D, Dutta M, Islam NF. Few plants and animals based folk medicines from Dibrugarh district, Assam. Indian Journal of Traditional Knowledge. 2006;4(1):81-85.

39. Kalita D, Baruah M. Ethnomedicine used by Mishings tribes of Dibrugarh district, Assam. Indian Journal of Traditional Knowledge. 2007;6(4):595-98.

40. Kalita D, Phukan B. Ethnomedicines used by the Tai Ahom of Dibrugarh district, Assam, India. Indian Journal of Natural Products and Resources. 2010;1(4):507-11.

41. Jain SK. Glimpses of Indian Ethnobotany. Oxford and IBH Publishing Co. New Delhi. 1987;231-41.

42. Martin GJ. Ethnobotany: A Methods Manual. Chapman and Hall, London, UK. 1995;102-04.

43. Jain, SK. A Manual of Ethnobotany. Scientific Publishers. Jodhpur, India. 1987.

44. Jain SK, Rao R. A handbook of field and herbarium methods. Today and Tomorrow's Printers and Publishers, New Delhi. 1977.

45. APG IV. An update of the angiosperm phylogeny group classification for the orders and families of flowering plants Botanical Journal of the Linnean Society. 2016;181(1):1-20. https://doi.org/10.1111/boj.12385.

46. Das AM, Athar M, Kumar M, Kumar R. FTIR analysis of for screening variation in antimicrobial activity of fresh and dried leaf extract of Rhynchostylis retusa: A threatened orchid species of Assam, North East India. Int Res J Pharm. 2013;18789. https://doi.org/10.7897/2230-8407.04741

47. Saxena S. The Current Research status of Endangered Rhynchostylis retusa (L.) Blume: A Review. Asian Journal of Research in Botany. 2020;4(2):16-25.

48. Molur S, Walker S. Report of the Workshop “ Conservation Assessment and Management Plan for selected medicinal plant species of northern, northeastern and central India” (BCPPEndangered Species Project), Zoo Outreach Organisation. Conservation Breeding Specialist Group, India. Coimbatore, India. $62 \mathrm{pp}$.

49. Taram M, Borah D, Tag H, Choudhary RK. An inventory of the native flowering plants in East Siang District of Arunachal Pradesh, India. Journal of Threatened Taxa. 2020;12(17):17299322.

50. Tag H, Jeri L, Mingki T, Tsering J, Das AK. Higher plant diversity in Pakke Wildlife Sanctuary and Tiger Reserve in East Kameng District of Arunachal Pradesh: Checklist-I. Pleione. 2012;6(1):149-62.

51. Choudhary RK, Srivastava RC, Das AK, Lee J. Floristc diversity assessment and vegetation analysis of Upper Siang District of Eastern Himalaya in North East India. Korean Journal of Plant Taxonomy. 2012;42(3):222-46.
52. Panda T, Pradhan BK, Mishra RK, Rout SD, Mohanty RD. Angiosperm diversity in Bhadrak region of Odisha, India. Journal of Threatened Taxa. 2020;12(3):15326-354. https://doi.org/10.11609/jott.4170.12.3.15326-15354

53. Klimes L, Dickore B. A contribution to the vascular plant flora of lower Ladakh (Jammu and Kashmir, India), Willdenowia. 2005;35(1):125-53. https://doi.org/10.3372/wi.35.35110

54. Bhatt V, Purohit VK. Floristic structure and phyto diversity along an elevational gradient in Peepalkoti-Joshimath area of Garhwal Himalaya, India. Nature and Science. 2009;7(9):63-74.

55. Paudel EN, Shrestha KK, Bhuju DR. Enumeration of herbaceous flora of Imja Valley, Sagarmatha National Park, Nepal: In: PK Jha and IP Khanal (eds.) Contemporary Research in Sagarmatha (Mt. Everest) Region, Nepal: An Anthology, Nepal Academy of Science and Technology, Lalitpur, Nepal. 2010;17388.

56. Kumar A, Mitra M, Singh G, Rawat GS. An inventory of the Flora of Binog Wildlife Sanctuary, Mussoorie, Garhwa Himalaya. Indian Journal of Fundamental and Applied Life Sciences. 2012;281-99.

57. Chhetri R, Bhattarai P. Floristic composition and diversity in Upper Manaslu Conservation Area, Central Nepal. Asian Journal of Conservation Biology. 2013;2(2):111-21.

58. Deshmukh P, Jain S. Assessment of Floristic Diversity in Miyar Valley of Lahaul and Spiti district, Himachal Pradesh, India. Journal of Global Resources. 2016;2:90-95.

59. Sapkota S, Pandey B, Shrestha KK. Diversity of Flowering Plants in Nubri Valley, Manaslu Conservation Area, Central Nepal. American Journal of Plant Sciences. 2017;8:6. https://doi.org/10.4236/ajps.2017.86102

60. Kalita D, Deb B. Some folk medicines used by the Sonowal Kacharis tribe of the Brahmaputra, Assam. Natural Product Radiance. 2004;3:4

61. Bhuyan A. Ethnomedicinal plants used by the Sonowal Kacharis of Dibrugarh district, Assam, India. International Journal of Applied Research. 2015;1(9):87-90.

62. 62. Samal PK, Mandal M. An inventory of the ethnobotanicals used as anti-diabetic by a rural community of Dhemaji district of Assam, Northeast India. Journal of Ethnopharmacology. 2011;138(2):345-50. https://doi.org/10.1016/j.jep.2011.08.018

63. Kabir MH, Hasan N, Rahman MM, Rahman MA, Khan JA. A survey of medicinal plants used by the Deb barma clan of the Tripura tribe of Moulvibazar district, Bangladesh. Journal of Ethnobiology and Ethnomedicine. 2014;10-19. https://doi.org/10.1186/1746-4269-10-19

64. Kalita D, Bonoranjan P. Folk medicine used by the Moran of Brahmaputra valley, Tinsukia district, Assam, India. Natural Product Radiance. 2009;8(1):73-76.

65. Sonowal R. Indigenous knowledge on the utilisation of medicinal plants by the Sonowal Kachari Tribe of Dibrugarh District in Assam, North-East India. International Research Journal of Biological Sciences. 2013;2(4):44-50.

66. Dixit S, Tiwari S. Investigation of anti-diabetic plants used among the ethnic communities of Kanpur division, India. Journal of Ethnopharmacology. 2020;article no. 112639. https:// doi.org/10.1016/j.jep.2020.112639

67. Parkash V, Saikia AJ, Dutta R, Borah D. Wild medicinal plants of Umtasoar Range under Nonghkyllem Reserve Forest Nongpoh, Meghalaya, India and their traditional usage by Khasi tribe- I. The Journal of Ethnobiology and Traditional Medicine. 2013;118:228-37.

68. Talukdar RT. Systematic studies on aroids of Kamrup district, Assam. (Ph.D. Thesis) Gauhati University, Guwahati. 2017.

69. Buragohain J. Ethnomedicinal Plants used by the ethnic communities of Tinsukia District of Assam, India. Recent Research in Science and Technology. 2011;3(9):31-42.

70. Shankar R, Deb S, Sharma BK. Antimalarial plants of northeast India: An overview. Journal of Ayurveda and Integrative Medicine. 2012;3(3):10-16. https://doi.org/10.4103/09759476.93940 
71. Daniel FA. Water Spinach (Ipomoea aquatica, Convolvulaceae) A food gone wild. Ethnobotany Research and Applications. 2007;5:123-46.

72. Patiri B, Borah A. Wild Edible Plants of Assam. Director Forest Communication, Forest Department, Assam. 2007.

73. Panda A, Misra MK. Ethnomedicinal survey of some wetland plants of South Orissa and their conservation. Indian Journal of Traditional Knowledge. 2011;10(2):296-303.

74. Swapna MM, Prakashkumar R, Anoop KP, Manju CN, Rajith NP. A review on the medicinal and edible aspects of aquatic and wetland plants of India. Journal of Medicinal Plant Research. 2011;5:7163-76.

75. Misra MK, Panda A, Sahu D. Survey of useful wetland plants of south Odisha, India. Indian Journal of Traditional Knowledge. 2012;11(4):658-66.

76. Bhardwaj S, Gakhar SK. Ethnobotanicals used by tribals of Mizoram for furniture and household equipments. Indian Journal of Traditional Knowledge. 2008;7(1):134-37.

77. Tripathy BK, Panda T, Mohanty RB. Traditional artifacts from 'Bena' grass (Vetiveria zizanioides (L.) Nash., Poaceae) in Jajpur district of Odisha, India. Indian Journal of Traditional Knowledge. 2014;13(4):771-77.

78. Mohanty RB, Tripathy BK, Panda T. Utilization of pith plant (Aeschynomene aspera L., Leguminosae: Papilionoideae) by traditional florists cum craftsmen in Jajpur District, Odisha, India. Nelumbo. https://doi.org/10.20324/nelumbo/v54/2012/57411

79. Bamin Y, Gajurel PR. Traditional use and Conservation of some selected plants used in Festivals and Rituals in Apatani Plateau of Arunachal Pradesh, India. International Journal of Conservation Science. 2015; 6(2):189-200

80. Sahu SK, Panda TS, Chand PK. Medico-botany of Plants used in rituals in coastal districts of Odisha. Cognitive Discourses. 2018; 6(1):12-27.

81. Borkataki S, Chutia M, Borthakur SK. Ethnobotany of biofencing species in teagarden and ex-teagarden community of Nagaon district of Assam. Indian Journal of Traditional Knowledge. 2008;7(4):666-68.

82. Mishra S, Vasudevan P, Prasad S. Biofencing: An ecofriendly boundry Wall. Journal of Scientific and Industrial Research. 2011;70:727-31.

83. Panda T, Mishra N, Pradhan BK, Mohanty R. Live fencing: An Ecofriendly boundry wall in Bhadrak district of Odisha, India. International Journal of Conservation Science. 2018;9(2):30110.

84. Siva R. Status of natural dyes and dye-yielding plants in India. Current Science. 2007;92(7):916-25.

85. Das PK, Mondal AK. Biodiversity and conservation of some dye yielding plants for justification of its economic status in the local areas of lateritic zone of West Bengal, India. Advances in Bioresearch. 2012;3(1):43-53.

86. Akimpou G, Rongmei R, Yadava PS. Traditional dye yielding plants of Manipur. Indian Journal of Traditional Knowledge. 2005;4(1):33-38.

87. Bhuyan R, Saikia CN. Isolation of colour components from native dye-bearing plants in northeastern India. Bioresource Technology. 2005; https://doi.org/10.1016/j.biortech.2004.02.032
88. Samanta AK, Agarwal P. Application of natural dyes on textiles. Indian Journal of Fibre and Textile Research. 2009;34:384-99.

89. Ghosh A. Traditional Vegetable dyes from Central West Bengal. Journal of Economy and Taxonomy Botany. 2003;27:825-26.

90. Kumar SV, Rao PSN. Dye yielding plants of Andaman \& Nicobar Islands. Journal of Economy and Taxonomy Botany. 2003;27(4):827-38.

91. Mahanta D, Tiwari SC. Natural dye yielding plants and indigenous knowledge on dye preparation in Arunachal Pradesh, northeast India. Current Science. 2005;88(9):1474-80.

92. Das PK, Mondal AK. Biodiversity and conservation of some dye yielding plants for justification of its economic status in the local areas of lateritic zone of West Bengal, India. Advances in Bioresearch. 2012;3(1):43-53.

93. Kar A, Borthakur SK. Dye yielding plants of Assam for dyeing handloom textile products. Indian Journal of Traditional knowledge. 2008;7(1):166-71.

94. Potsangbam L, Ningombam S, Laitonjam WS. Natural dye yielding plants and indigenous knowledge of dyeing in Manipur, Northeast India. Indian Journal of Traditional Knowledge. 2008;7(1):141-47.

95. Teron R, Borthakur SK. Traditional knowledge of herbal dyes and cultural significance of colors among the Karbis ethnic tribe in northeast India. Ethnobotany Research and Applications. 2002;10:593-603.

96. Sutradhar B, Deb D, Majumdar K, Datta BK. Traditional dye yielding plants of Tripura, northeast India. Biodiversitas. 2015;16(2):121-27.

97. Khanikar G. Sahaj labhoya bon-darabar goon. Khanikar Puthibharal, Tetelitol, Golaghat, Assam, India. 2002.

98. Das KK. Pattern of dermatological diseases in Gauhati medical college and hospital Guwahati. Indian Journal of Dermatology, Venereology and Leprology. 2003;69(1):16-18.

99. Saikia AP, Ryakala VK, Sharma P, Goswami P, Bora U. Ethnobotany of medicinal plants used by Assamese people for various skin ailments and cosmetics. Journal of Ethnopharmacology. 2006;106(2):149-57. https://doi.org/10.1016/ j.jep.2005.11.033

\section{Additional information}

Peer review information: Plant Science Today thanks Sectional Editor and the other anonymous reviewers for their contribution to the peer review of this work.

Reprints and permissions information is available at https://horizonepublishing.com/journals/index.php/PST/open_access_policy

Publisher's Note: Horizon e-Publishing Group remains neutral with regard to jurisdictional claims in published maps and institutional affiliations.

To cite this article: Gogoi P, Nath N. Diversity and inventorization of angiospermic flora in Dibrugarh district, Assam, Northeast India. Plant Science Today. 2021;8(3):621-628.

https://doi.org/10.14719/pst.2021.8.3.1118

Plant Science Today, published by Horizon e-Publishing Group, is covered by Scopus, Web of Science, BIOSIS Previews, Clarivate Analytics, etc. See https://horizonepublishing.com/journals/index.php/PST/indexing_abstracting 